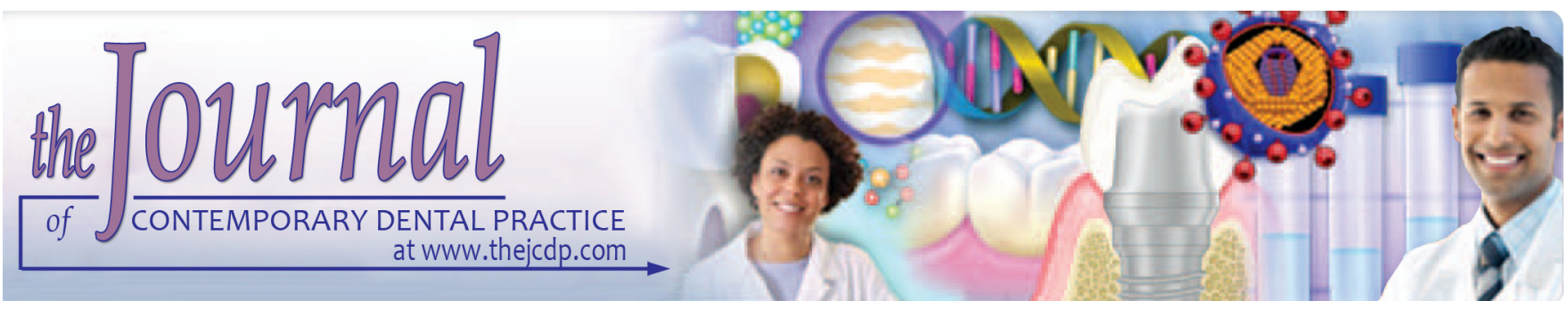

\title{
Deoxyribonucleic Acid Probes Analyses for the Detection of Periodontal Pathogens
}

\author{
'Zoubeida AL Yahfoufi, ${ }^{2}$ Wahib Hadchiti, ${ }^{3}$ Antoine Berberi
}

\begin{abstract}
Background: In clinical microbiology several techniques have been used to identify bacteria. Recently, Deoxyribonucleic acid (DNA)-based techniques have been introduced to detect human microbial pathogens in periodontal diseases. Deoxyribonucleic acid probes can detect bacteria at a very low level if we compared with the culture methods. These probes have shown rapid and cost-effective microbial diagnosis, good sensitivity and specificity for some periodontal pathogens in cases of severe periodontitis.
\end{abstract}

Materials and methods: Eighty-five patients were recruited for the study. Twenty-one subjects ranging between 22 and 48 years of age fulfilled the inclusion and exclusion criteria. Seventy-eight samples became available for DNA probe analysis from the deepest pockets in each quadrant.

Results: All 21 patients showed positive results for Prevotella intermedia; also, Prevotella gingivalis was identified in 19 subjects, Aggregatibacter actinomycetemcomitans in 6 subjects. P. intermedia was diagnosed positive in $82 \%$ of the subgingival samples taken, $79 \%$ for $P$. gingivalis, and $23 \%$ for A. actinomycetemcomitans.

Conclusion: This study shows a high frequency of putative periodontal pathogens by using DNA probe technology, which is semi-quantitative in this study. Deoxyribonucleic acid probes can detect bacteria at very low level about $10^{3}$ which is below the detection level of culture methods. The detection threshold of cultural methods.

Clinical significance: The three types of bacteria can be detected rapidly with high sensitivity by using the DNA probe by general practitioners, and thus can help in the diagnosis process and the treatment.

\footnotetext{
1,2Department of Periodontology, School of Dentistry, Lebanese University, Beirut, Lebanon

${ }^{3}$ Department of Oral and Maxillofacial Surgery, School of Dentistry, Lebanese University, Beirut, Lebanon

Corresponding Author:Antoine Berberi, Professor, Department of Oral Surgery, School of Dentistry, Lebanese University Beirut, Lebanon, Phone: +961-3-731173, e-mail: anberberi@ gmail.com
}

Keywords: A. actinomycetemcomitans, DNA probes, $P$. intermedia, $P$. gingivalis, Periodontal disease.

How to cite this article: Yahfoufi ZAL, Hadchiti W, Berberi A. Deoxyribonucleic Acid Probes Analyses for the Detection of Periodontal Pathogens. J Contemp Dent Pract 2015;16(9): 727-732.

\section{Source of support: Nil}

Conflict of interest: None

\section{INTRODUCTION}

It is well known that periodontitis is an infectious disease caused by bacteria, notably Gram-negative species. The number of bacterial species that can inhabit periodontal lesions has been estimated at more than 500, of which about $50 \%$ can be cultured. ${ }^{1}$ In recent years, only few bacteria have been associated with disease progression, the number of cultivable species is limited to less than 10 which include: Aggregatibacter actinomycetemcomitans, Eikenella, Campylobacter, Porophyromonas, Prevotella, Fusobacterium, Tannerella and Treponema. ${ }^{2,3}$ The prevalence of periodontitits in human beings is about $30 \%$, of whom 10 to $15 \%$ have a severe form of the disease. ${ }^{4-6}$

In oral microbiology several techniques have been used to identify bacteria. For the analysis of subgingival plaque, anaerobic bacteria culture has been the gold standard for many years. ${ }^{7}$ Recently, molecular microbial techniques have become available helping to identify quantity target organisms with high specificity and sensitivity. The technique of real-time polymerase chain reaction (RT-PCR) provides a new tool to detect oral pathogens, ${ }^{8}$ in addition to the DNA probe technique, which is also used as a detection method.

Microbiological tests are available to dentists in order to determine the presence of these microorganisms. There is a big discussion if these microbial tests can help the patients in clinical practices. Mombelli et $\mathrm{al}^{10}$ in a previous study, addressed the question of: Are the 
presence of these periodontal pathogens in a high level can differentiated between subjects with chronic or aggressive periodontitits, and whether microbial testing could either indicate success or failure of conservative treatment earlier than a clinical assessment. ${ }^{11}$ The most important aspect of any microbial test is its sensitivity and specificity in identifying these microorganisms; it is also important for it to be rapid and easy to use by dentists.

The aim of the present study is to describe the DNA technique in detecting three microorganisms Porphyromonas gingivalis, Prevotella intermedia, and A. actinomycetemcomitans in patients with minimal periodontal disease, defined by a mean probing depth $<3.5 \mathrm{~mm}$ and the presence of less than $5 \%$ of pockets deeper than $5 \mathrm{~mm}$.

\section{MATERIALS AND METHODS}

This was a descriptive and analytical cross-sectional study in which a quantitative DNA-probe data collection method was used. This study was conducted in accordance with the Helsinki agreement for research on humans; ethical clearance was obtained, and every participant signed an informed consent. Eighty-five patients in total (65 males and 20 females) ranging between 22 and 48 years of age were screened for participation in this study.

Inclusion criteria: Patients should have a least 20 teeth in their mouths with no history of dental care except extractions and fillings, the presence of minimal periodontal disease, defined by a mean probing depth $<3.5 \mathrm{~mm}$ and the presence of less than $5 \%$ of pockets deeper than $5 \mathrm{~mm}$.

Exclusion criteria: Patients with systemic diseases were excluded, as well as pregnant women. Patients with history of antibiotics or antiseptic treatments for the last 6 months were excluded also. Only 21 subjects who fulfilled the following clinical criteria, 16 males and 5 females (ranging between 29 and 33 years of age) were included in the study.

\section{Plaque Sampling and Clinical Measurements}

First, The plaque index (PI) Silness et $\mathrm{al}^{12}$ was scored on four surfaces of every tooth. Then, subgingival microbiological samples were taken with paper-points from the deepest pocket in each quadrant as described in Mombelli et al ${ }^{7,13}$ Supragingival plaque was removed with sterile cotton pellets before sampling. The area was isolated and dried; one sterile paper point (Absorbent points 2715 fine, Johnson and Johnson, NJ, USA) was inserted to the bottom of a pocket for a period of 10 seconds. ${ }^{7,13}$ After sampling, probing of the pocket depth and recession were measured, bleeding on probing was determined on four surfaces of each tooth. One single investigator (ZA) collected all clinical indices and samples. A standard periodontal probe (GF-w, Hu-Freddy, 11, USA) was used for periodontal probing.

\section{DNA Probe Analysis of Bacteria}

Commercially available DNA probes were used for specific identification and quantification of A. actinomycetemcomitans, P. gingivalis, and P. intermedia (Omni Gene, MA, USA; ANAWA Laboratories, Switzerland). The probes were used as described by French et $\mathrm{al}^{14}$ In brief, the processing of specimens of dental plaque for DNA probe analysis required disruption of the bacterial cells and the denaturing of the DNA molecules into two separate strands. This was accomplished by suspending the plaque specimens in a high $\mathrm{pH}$ solution $(0.3 \%$ sodium dodecyl sulphate, $10 \mathrm{mM} \mathrm{NaOH}$ ) and subsequent boiling. The samples were then equilibrated with loading buffer (1:I [v/v] of $0.3 \mathrm{M} \mathrm{NaOH}, 3 \mathrm{M} \mathrm{NaCI}: 2 \mathrm{M} \mathrm{NH}, \mathrm{OAc}$ ), applied to nitrocellulose filters, rinsed in $0.5 \mathrm{M} \mathrm{NaCl}$, air-dried and baked at $80^{\circ} \mathrm{C}$ for 2 hours. After prehybridization with Denhard's solution, containing $20 \mathrm{mg} / \mathrm{ml}$ of salmon sperm DNA, for 1 hour at $65 \mathrm{~T}$, the filters were hybridized with the corresponding P 32-labeled DNA-probe for 4 hours with WASH I $(0.18 \mathrm{M} \mathrm{NaCl}, 10 \mathrm{mM}$ sodium phosphate, $1 \mathrm{mM}$ EDTA, pH 7.4, 0.1\% sodium dodecyl sulfate) and twice at $65^{\circ} \mathrm{C}$ for 15 minutes with WASH I1 $(1 \times \mathrm{SSPE}=0-18 \mathrm{M} \mathrm{NaC1}, 10 \mathrm{mM}$ sodium phosphate buffer, $1 \mathrm{~m}$ M EDTA, pH 7.4, 0.1 per cent sodium dodecyl sulphate). The filters were then air-dried and exposed to Kodak X-OMAT AR film (Kodak, Switzerland) for 48 hours at $-70^{\circ} \mathrm{C}$ using an intensifying screen. The developed $X$-ray films were recorded with a video camera and digitally processed using image analysis-software (Image 1.47, NIH, MD, USA). Each of the three filters for A. actinomycetemcomitans, $P$. gingivalis, and $P$. intermedia contained $10^{5}, 10^{4}$ and $10^{3}$ control-cells in triplicate, which were used as references for a standard curve. Each patient sample was measured and compared with the reference curve to give a numerical value representing the number of specific bacteria present in the plaque samples.

\section{RESULTS}

\section{Clinical Parameters}

Out of 85 subjects screened for participation in this study, 15 individuals were not included, because they were considered periodontally healthy, while 30 were excluded because they showed evidence of more than minimal periodontal disease. A further 19 subjects were not included because they missed one or more of the other criteria. 
The age and sex of the subjects were recorded together with the use of antibiotics in the last 5 years, frequency of teeth brushing and smoking habits are listed in Table 1.

Table 1: Age, sex and origin, exposure to antibiotics in the last 5 years, frequency of tooth-brushing and smoking habits of the 21 study subjects

\begin{tabular}{llllll}
\hline Patient & Age & Sex & $\begin{array}{l}\text { Antibiotics } \\
\text { last 5 years }\end{array}$ & Brushing & Smoking $>1$ \\
pack/day
\end{tabular}

Table 2: Number of positive samples for $A$. actinomycetemcomitans (Aa), $P$. gingivalis $(\mathrm{Pg})$ and $P$. intermedia $(\mathrm{Pi})$

\begin{tabular}{lllll}
\hline Patient & $A A$ & $P G$ & $P I$ & $\begin{array}{l}\text { Total number } \\
\text { of samples }\end{array}$ \\
\hline 1 & 0 & 4 & 4 & 4 \\
2 & 4 & 4 & 4 & 4 \\
3 & 0 & 1 & 1 & 4 \\
4 & 4 & 4 & 4 & 4 \\
5 & 4 & 4 & 4 & 4 \\
6 & 4 & 4 & 4 & 4 \\
7 & 1 & 4 & 2 & 4 \\
8 & 0 & 3 & 3 & 4 \\
9 & 0 & 3 & 4 & 4 \\
10 & 0 & 4 & 4 & 4 \\
11 & 0 & 3 & 4 & 4 \\
12 & 0 & 4 & 2 & 4 \\
13 & 0 & 3 & 3 & 4 \\
14 & 0 & 3 & 4 & 4 \\
15 & 1 & 4 & 3 & 4 \\
16 & 0 & 4 & 2 & 4 \\
17 & 0 & 2 & 4 & 4 \\
18 & 0 & 2 & 1 & 1 (3 sites) \\
19 & 0 & 0 & 3 & 4 \\
20 & 0 & 2 & 1 & 1 (3 sites) \\
21 & 0 & 0 & 4 & 4 \\
\hline Total & 18 & 62 & 64 & 78 \\
\hline & & & &
\end{tabular}

The average plaque index was 1.17. The mean pocket depth was $2.70 \mathrm{~mm}$, the mean recession amounted to $0.30 \mathrm{~mm}$ and the percentage of sites bleeding upon probing was $62 \%$ (Graph 1).

\section{Microbiological Parameters}

Table 2 showed the presence of the three periodontal pathogens $A$. actinomycetemcomitans, $P$. gingivalis and $P$. intermedia $0.23 \%$ of all samples were $A$. actinomycetemcomitans positive, $79 \%$ were positive for $P$. gingivalis and $82 \%$ for $P$. intermedia (Graph 2). The amount and the association of the three marker organisms in the $78 \mathrm{sub}$ gingival samples from 21 patients are shown in Graph 3. Graph 3A shows the distribution of $P$. gingivalis and $P$. intermedia in A. actinomycetemcomitans negative samples (AA: $n d, n=60$ ). Graph 3B shows the same relationship when $A$. actinomycetemcomitans is present at a level below $10^{4}\left(\mathrm{AA}: 10^{3} \mathrm{Vn}=7\right)$. Graph $3 \mathrm{C}$ lists the 11 samples with A. actinomycetemcomitans at a level above $10^{4}$ (Each square represents one sample and nd $=$ not detected).

The statistic analysis showed highly significant Fischer's exact test). The majority of $P$. gingivalispositive samples were also positive for $P$. intermedia (Table $3 \mathrm{~A}$ ); only $8 \%$ of all samples were positive for $P$. gingivalis but not for $P$. intermedia and only $6 \%$ were $P$. Intermedia, but not $P$. gingivalis positive. Statistically, the association between these two species is highly significant Fischer's exact test). Table 3B shows the relationship between $P$. gingivalis and A. actinomycetemcomitans. This association was also statistically significant $(\mathrm{p}=0.016)$ all A. actinomycetemcomitans-positive samples were also $P$. gingivalis-positive. No significant relationship was found between $P$. intermedia and $A$. actinomycetemcomitans (Table 3C).

Table 3: Presence of $P$. gingivalis in relation to presence of $P$. intermedia (A), A. actinomycetemcomitans in relation to $P$. gingivalis (B) and $A$. actinomycetemcomitans in relation to $P$. intermedia (C) in 78 samples evaluated

\begin{tabular}{llll}
\hline & & \multicolumn{2}{c}{ P. gingivalis } \\
\cline { 3 - 4 } A & & Found & Not found \\
\hline P. intermedia & Found & 56 & 6 \\
& Not found & 5 & \\
& & \multicolumn{2}{c}{ P. gingivalis } \\
\hline \multirow{3}{*}{$\begin{array}{llll}\text { A. actinomycetemcomitans } \\
\text { C }\end{array}$} & Found & Found & Not found \\
& Not found & 44 & 0 \\
\hline & & \multicolumn{2}{c}{ P. intermedia } \\
A. actinomycetemcomitans & Found & 18 & 13 \\
& Not found & 47 & Found \\
\hline
\end{tabular}




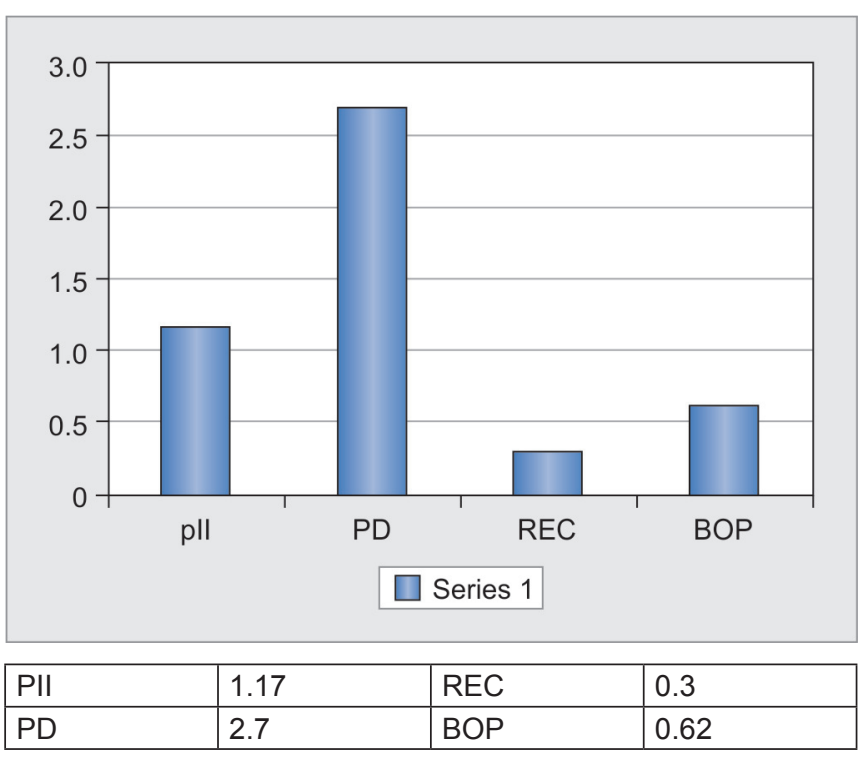

Graph 1: Mean values of clinical measurements in the 21 patients

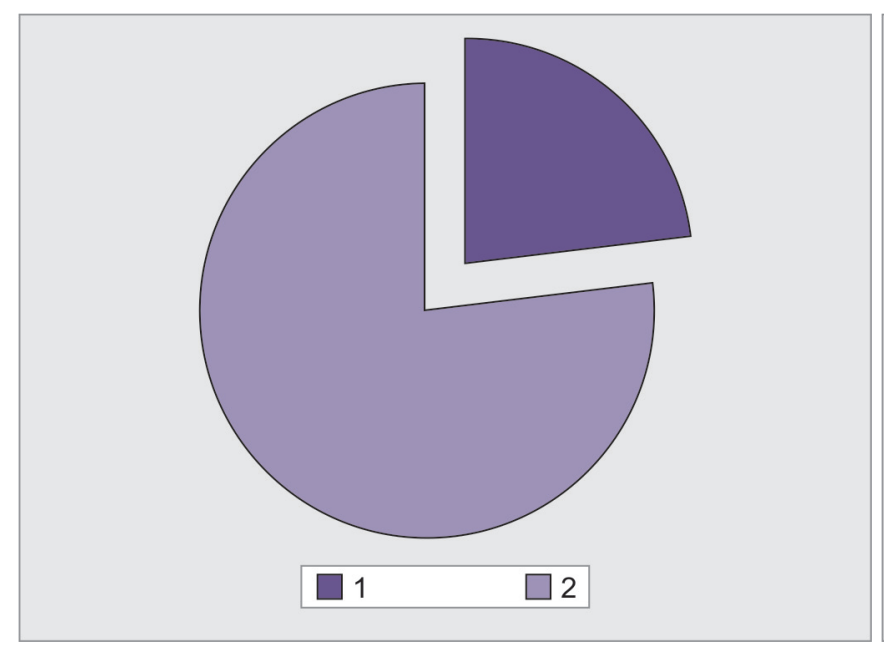

\begin{tabular}{|l|l|}
\hline $\mathrm{Pg}$ & 79 \\
\hline 1 & \\
\hline
\end{tabular}

\section{DISCUSSION}

Testing periodontal pathogens should be concentrated on a small group of patients. Subjects for whom microbial testing is indicated include:

- Patients with aggressive periodontitis.

- Patients ranging between 25 and 35 years of age, with rapid destruction of attachment and bone loss in relatively a short period of time.

- Patients who continue to lose attachment despite adequate treatment.

Before using any microbial tests we should complete the phase one of the therapy (mechanical treatment and oral hygiene control). This is a essential condition for using any tests, and to be useful these information since we believe that periodontal diseases are site specific disease, clinicians must get an overview on the first session before sampling. The sample should be collected in a second

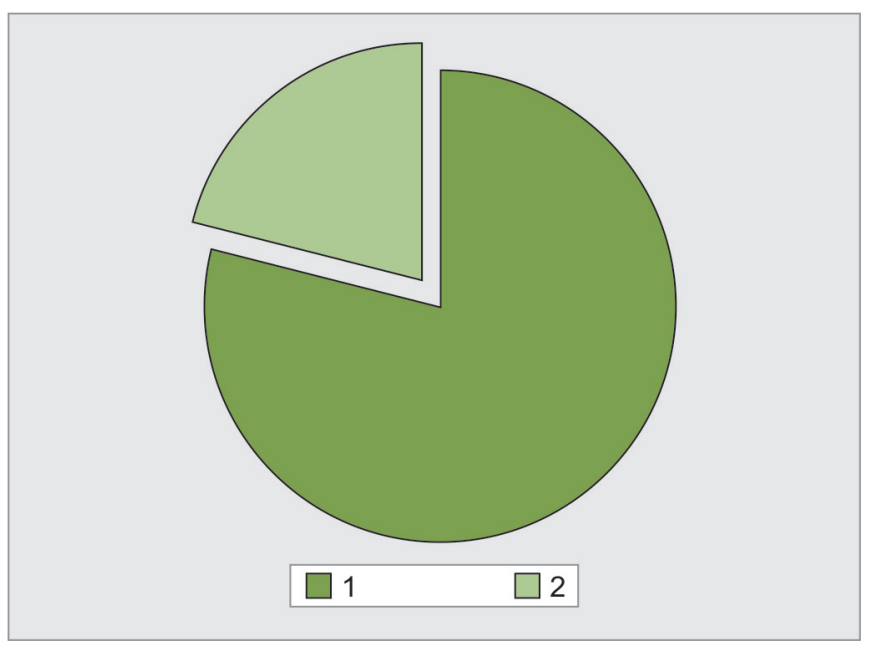

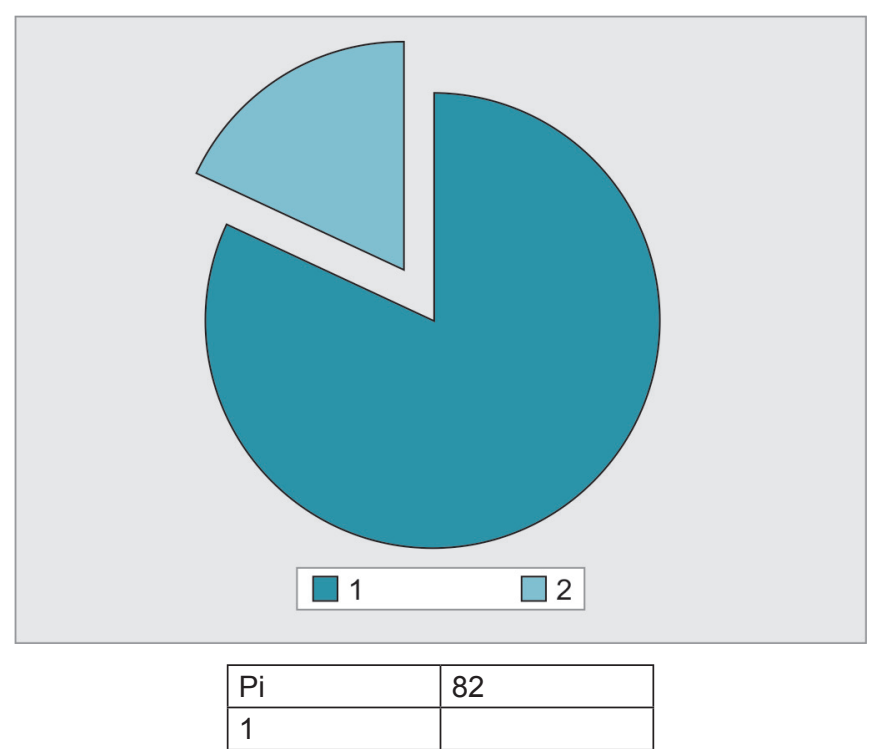

Graph 2: Frequency of $A$. actinomycetemcomitans $(\mathrm{Aa}), P$. gingivalis $(\mathrm{Pg})$ and $P$. intermedia $(\mathrm{Pi})$ in 78 subgingival samples 


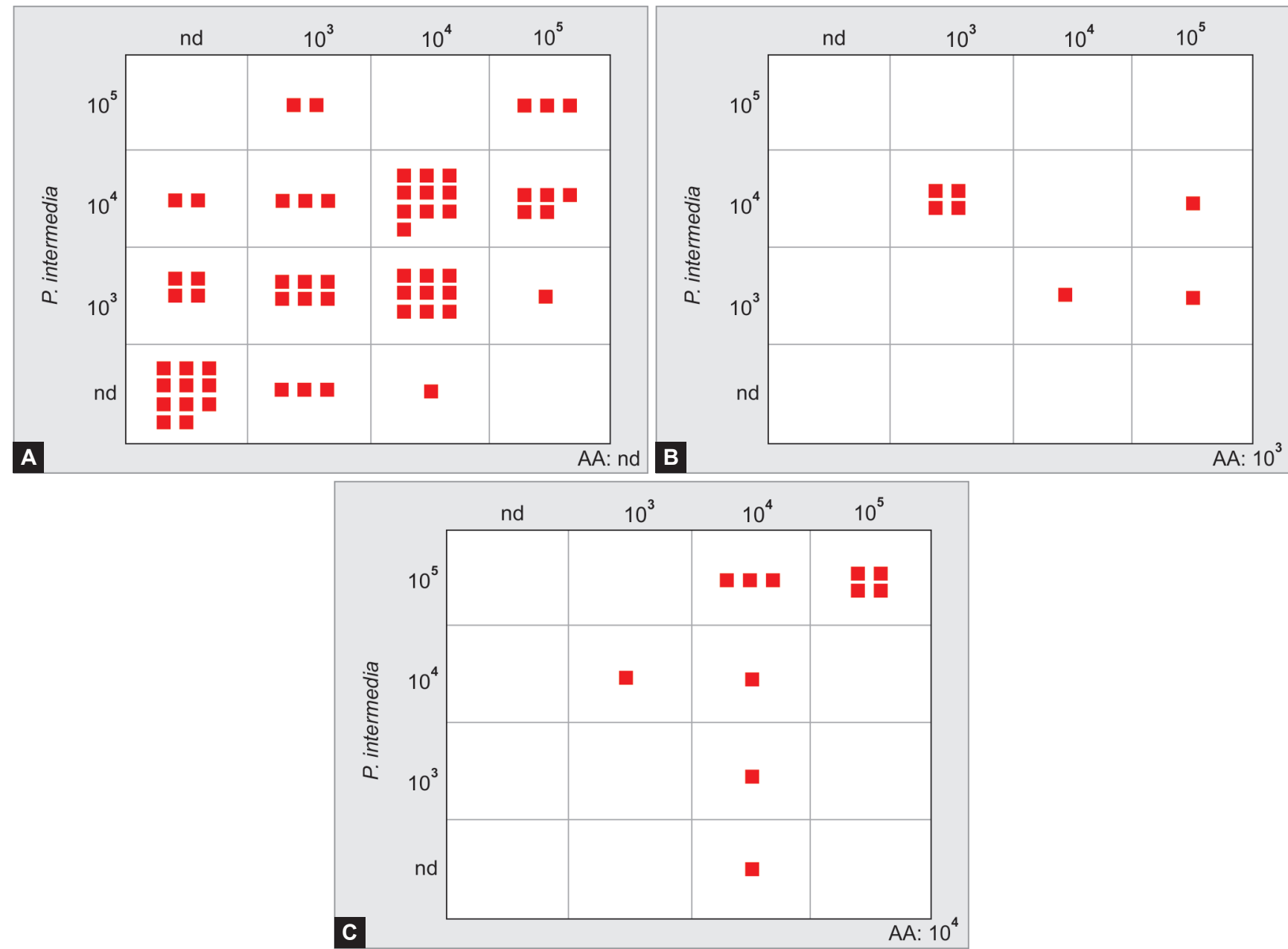

Graphs $3 A$ to $C$ : The amount and the association of the three marker organisms in 78 subgingival samples from 21 patients: $(A)$ The distribution of $P$. gingivalis and $P$. intermedia in $A$. actinomycetemcomitans negative samples (AA: $n d, n=60)$. (B) The same relationship when $A$. actinomycetemcomitans is present at a level below $10^{4}\left(A A: 10^{3}, n=7\right)$ and $(C)$ The 11 samples with $A$. actinomycetemcomitans at a level above $10^{4}$. Each square represents one sample (nd: not detected)

session so as to avoid provocation of bleeding, ${ }^{16}$ from the deepest pocket. In this case, a diagnostic result can be representative of the entire mouth's condition.

Two different molecular genetics strategies have been introduced to detect periodontal pathogens in subgingival plaque, based on (1) genomic or oligonucleotide DNA Probes (2) PCR Test (Murray).

The aim of the study was to determine the associations between the three marker periodontopathogens ( $\mathrm{Aa}, \mathrm{Pg}, \mathrm{Pi}$ ) to evaluate their levels in subgingival plaque of patients with minimal periodontal disease and to describe our experience with commercial test systems for the detection of pathogens.

There is evidence linking $A$. actinomycetemcomitans and $P$. gingivalis with pathogenesis of periodontitis, ${ }^{17,18}$ also a positive correlation between both microbes indicates the existence of a synergistic association between A. actinomycetemcomitans and $P$. gingivalis as was previously described, ${ }_{19}^{19}$ the fact that two pathogens were present in health and disease indicates that the level of these bacteria is more significant with regard to the disease progression, ${ }^{20}$ which supports the hypothesis that periodontal disease is associated with a shift in the balance of the sub-gingival microbiota rather than the action of a single pathogen or a simple increase in diversity. ${ }^{21}$

There was a significant association between $P$. gingivalis and $A$. actinomycetemcomitans in the present study and also in several studies 8,13 , and a highly association was observed between gingivalis and $P$. intermedia in 56 sites both species were found at the same time. In contrast, ${ }^{22,23}$ reported an inverse relationship between $P$. gingivalis and $P$. intermedia, with patients diagnosed with advanced periodontitis.

Culture, however, has several disadvantages. It is time consuming and has a law sensitivity this is because of the slow growth of some oral pathogens, and maybe for this reasons, several alternative techniques have been developed for the detection of periodontal pathogens, such as immunoassays,${ }^{24}$ DNA probes assays, ${ }^{24-26}$ and PCR assays. ${ }^{27-30}$

This study shows a high frequency of putative periodontal pathogens by using the DNA probe technology. The test is semi-quantitative. It has been reported that DNA probes can be detected at levels below the detection 
threshold of cultural methods; it is specific, sensitive, rapid and easy to use by general practitioners. The present study demonstrates high prevalence of periodontal pathogens in a group of Middle-Eastern subjects with minimal periodontal disease. It may be assumed that the oral micro flora of these subjects developed over several years without any external disturbances since this group of patients has no exposure to dental care except extraction and fillings.

\section{ACKNOWLEDGMENTS}

The authors would like to thank Mr Walter Burgin, Biomedical Engineer, University of Bern, School of Dental Medicine, for his assistance in the data analysis, and also to thank Dr A Wicki and ANAWA Laboratories, Switzerland for the entire DNA probes analysis.

\section{REFERENCES}

1. Paster BJ, Boches SK, Galvin JL, Ericson R, Lau CN, Levanos VA, Sahasrabudhe A, Dewhirst FE. Bacterial diversity in human subgingival plaque. J Bacteriol 2001;183:3770-3783.

2. Feng X, Zhang L, Xu L, Meng H, Lu R, Chen Z, et al. Detection of eight periodontal microorganisms and distribution of Porphyromonas gingivalis fimA genotypes in Chinese patients with aggressive periodontitis. J Periodontol 2014; 1:150-159.

3. Lafaurie GI, Contreras A, Baron A, Botero J, Mayorga-Fayad I, Jaramillo A, et al. Demographic, clinical and microbial aspects of chronic and aggressive periodontitis in Colombia: a multicenter study. J Periodontol 2007;4:629-39.

4. Brown LJ, Oliver RC, Loe H. Periodontal diseases in the U.S. Prevalence severity extent and role in tooth mortality. J Periodontol 1989;60:363-370.

5. Papapanou PN. Periodontal diseases. Epidemiology Ann Periodont 1996;1:1-36.

6. Oliver, RC Brown LJ, Loe H. Periodontal diseases in the United States population. J Periodontol periodont Dis Epidemiol 1998;69:269-278.

7. Mombelli A, McNabb H, Lang NP. Black pigmenting Gram-negative bacteria in periodontal disease. II. Screening strategies for P. gingivalis. J Periodont Res 1991;26:308-313.

8. Boutaga K, van Winkelhoff AJ, Vandenbroucke-Grauls CM, Savelkoul PH. Periodontal pathogens a quantitive comparison of anaerobic culture and real time PCR. FEMS Immunol Med Microbiol 2005;45:191-199.

9. Boutaga K, van Winkelhoff AJ, Vandenbroucke-Grauls CM, Savelkoul PH. Comparison of real time PCR and culture of detection of porphyromonas gingivalis in subgingival plaque samples. J Clin Microbiol 2003;41:4950-4954.

10. Mombelli A, Casagni F, Madianos PN. Can presence or absence of periodontal pathogens distinguish between subjects with chronic and aggressive periodontitits? A systematic review. J Clin Periodontal 29 Suppl 2002;3:10-21.

11. Brochut P, Marin I, Baehni PC, Mombelli A. Predictive value of clinical and microbiological parameters for the treatment outcome of scaling and root planning. J Clin Periodont 2005; 32:695-701.

12. Parihar AS, Katoch V, Rajguru SA, Rajpoot N, Singh P, Wakhle S. Periodontal Disease: a possible risk-factor for adverse pregnancy outcome. J Int Oral Health 2015;7:137-142.

13. Mombelli A, Gmur R, Gobbi C, Lang NP. Actinobacillus actinomycetemcomitans in adult periodontitis. I. Topographic distribution before and after treatment. J Periodontol 1994;65: 820-826.

14. French CK, Savitt ED, Simon SL, Ekiund SM, Chen MC, Klotz LC, Vaccaro KK. DNA probe detection of periodontal pathogens. Oral Microbiol Immunol 1986;1:58-62.

15. Conrads G. Testing for marker bacteria in progressive periodontitis the European experience. Infect Dis Clin Pract 2002;10:481-487.

16. Mombelli A, McNabb H, Lang NP. Distribution patterns of black-pigmented Gram-negative bacteria in periodontits patients. FEMS Immunol Med Microbiol 1993;6:199.

17. Liu LL, Wen X, He H, Shi J Ji C. Species-specific DNA probe for the detection of Porphyromonas gingivalis from adult Chinese periodontal patients and healthy subjects. J Periodont 2003;74:1000-1006.

18. Cortelli JR, Cortelli SC, Jordan SF, Haraszthy VI, Zambon JJ. Prevalence of periodontal pathogens in Brazilians with aggressive or chronic periodontitis. J Clin Periodontol 2005; 32:860-866

19. Slots J, Ting M. Actinobacillus actinomycetemcomitans and Porphyromona gingivalis in human periodontal disease. Occurrence and treatment. Periodontol 2000;22:82-121.

20. Ledder RG, Gilbert P, Huws SA, Aarons L, Ashley MP, Hull PS, Mc Bain AJ. Molecular analysis of the subgingival microbiota in health and disease. Appl Environ Microbiol 2007;73:516-523.

21. Ly M, Abeles SR, Boehm TK, Robles-Sikisaka R, Naidu M, Santiago-Rodriguez T, Pride DT. Altered oral viral ecology in association with periodontal disease. MBio 2014 May 20;5:e01133-1114.

22. Fritoli A, Gonçalves C, Faveri M, Figueiredo LC, PérezChaparro PJ, Fermiano D, Feres M. The effect of systemic antibiotics administered during the active phase of nonsurgical periodontal therapy or after the healing phase: a systematic review. J Appl Oral Sci 2015;23:249-254.

23. Ali RW, Lie T, Skaug N. Early effects of periodontal therapy on the detection frequency of four putative periodontal pathogens in adults. J Periodontol 1992;63:540-547.

24. Loesche WJ. DNA probe and enzyme analysis in periodontal diagnostics. J Periodontol 1992;63:1102-1109.

25. Savitt ED, Keville MW, Peros WJ. DNA probes in the diagnosis of periodontal microorganisms Arch Oral Biol 1990;35:153S-159S.

26. Savitt ED, Strzempko MN, Vaccaro KK, Peros WJ, French CK. Comparison of cultural methods and DNA probe analyses for the detection of Actinobacillus actinomycetemcomitans, Bacteroides gingivalis, and Bacteroides intermedius in subgingival plaque samples. J Periodontol 1988;59:431-438.

27. Ashimoto A, Chen C, Bakker I, Slots J. Polymerase chain reaction detection of 8 putative periodontal pathogens in subgingival plaque of gingivitis and advanced periodontitis lesions. Oral Microbiol Immunol 1996;11:266-273.

28. Lyons SR, Griffen AL, Leys EJ. Quantitative real-time PCR for Porphyromonas gingivalis and total bacteria. J Clin Microbiol 2000;38:2362-2365.

29. Nozaki T, Kusumoto Y, Kitamura M, Hirano H, Kohyama A, Hayakawa M, Takiguchi H, Abiko Y, Murakami S, Okada H. A sensitive method for detecting Porphyromonas gingivalis by polymerase chain reaction and its possible clinical application. J Periodontol 2001;72:1228-1235.

30. Sakamoto M, Takeuchi $Y$, Umeda M, Ishikawa I, Benno $Y$. Rapid detection and quantification of five periodontopathic bacteria by real-time PCR. Microbiol Immunol 2001;45:39-44. 